\title{
Updates in Management and Timing of Dialysis in Acute Kidney Injury
}

\author{
Margaret K Yu, MD, MS*; Fahmeedah Kamal, MD; Glenn M Chertow, MD, MPH¹ \\ 'Division of Nephrology, Department of Medicine, Stanford University School of Medicine, Stanford, California
}

Acute kidney injury (AKI) is a common complication in hospitalized patients and is associated with mortality, prolonged hospital length of stay, and increased healthcare costs. This paper reviews several areas of controversy in the identification and management of AKI. Serum creatinine and urine output are used to identify and stage AKI by severity. Although standardized definitions of AKI are used in research settings, these definitions do not account for individual patient factors or clinical context which are necessary components in the assessment of AKI. After treatment of reversible causes of $\mathrm{AKI}$, patients with $A K I$ should receive adequate volume resuscitation with crystalloid solutions. Balanced crystalloid solutions generally prevent severe hyperchloremia and could potentially reduce the risk of $\mathrm{AKI}$, but additional studies are needed to demonstrate a clinical benefit. Intravenous albumin may be beneficial in patients with chronic liver disease either to prevent or attenuate the severity of $\mathrm{AKI}$; otherwise, the use of albumin or other colloids (eg, hydroxyethyl starch) is not recommended. Diuretics should be used to treat volume overload, but they do not facilitate AKI recovery or reduce mortality. Nutrition consultation may be helpful to ensure that patients receive adequate, but not excessive, dietary protein intake, as the latter can lead to azotemia and electrolyte disturbances disproportionate to the patient's kidney failure. The optimal timing of dialysis initiation in AKI remains controversial, with conflicting results from two randomized controlled trials. Journal of Hospital Medicine 2019;14:232-238. Published onfline first February 20, 2019. (C) 2019 Society of Hospital Medicine

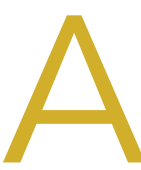

cute kidney injury (AKI) is a common complication in hospitalized patients, affecting one in five inpatients ${ }^{1,2}$ and more than half of patients in intensive care units (ICU). ${ }^{3}$ The incidence of AKI appears to be increasing over time. ${ }^{4}$ Potential contributing factors include an aging population, rising prevalence of comorbid conditions such as heart failure and chronic kidney disease (CKD), using nephrotoxic agents, and increasing complexity of surgical procedures. ${ }^{5,6} \mathrm{AKI}$ during a hospital stay is associated with a two- to 10-fold increased risk of inhospital mortality, ${ }_{1}^{1,2,7-10}$ longer hospital length of stay, ${ }^{7,10}$ higher risk for hospital readmissions, ${ }^{11}$ and higher healthcare costs. ${ }^{7}$ Patients who survive an episode of AKI have a higher risk for CKD and dialysis-dependence, ${ }^{9}$ even after an episode of reversible AKI. ${ }^{12}$ Despite its clinical importance, several areas of controversy remain regarding the management of $A K I$ and, in particular, the optimal timing of renal replacement therapy (RRT) in patients with AKI. The purpose of this manuscript is to review the approaches to diagnosis and management of AKI in hospitalized patients. We also review recent evidence regarding the timing of dialysis in patients with AKI. This journal recently reviewed the differential diagnosis and diagnostic evaluation of $\mathrm{AKI}$, which is not covered here. ${ }^{13}$

*Corresponding Author: Margaret Yu, MD, MS; E-mail: mkyu@stanford.edu.

Received: March 15, 2018; Revised: September 26, 2018;

Accepted: October 2, 2018

() 2019 Society of Hospital Medicine DOI 10.12788/jhm.3105

\section{DEFINITION OF ACUTE KIDNEY INJURY}

$A K I$ refers to an acute change in kidney function characterized by an increase in serum creatinine and/or a reduction in urine output. It is a clinical syndrome caused by a broad range of etiologies and may be related to primary kidney pathology and/or systemic illness. Until 2004, there was no standard definition for $\mathrm{AKI}$ and over 30 different definitions were found in the literature, which resulted in wide variation in the reported incidence and outcomes of AKI and made it challenging to apply an evidence-based approach to patient care. In 2004, the Risk, Injury, Failure, Loss, and End-stage kidney disease (RIFLE) ${ }^{14}$ criteria for AKI were proposed, which were modified to the Acute Kidney Injury Network (AKIN) ${ }^{15}$ criteria in 2007 (Table 1). Multiple studies show that the RIFLE and AKIN criteria for AKI are associated with higher mortality ${ }^{1,2,8,10}$ and increased risk for requiring RRT. ${ }^{1,10}$

International clinical practice guidelines for AKI were released by Kidney Disease: Improving Global Outcomes (KDI$\mathrm{GO}$ ) in 2012, which included a standardized definition of AKI that was adapted from the previously validated RIFLE and AKIN definitions. ${ }^{16}$ Patients are considered to have AKI when the serum creatinine rises by as little as $0.3 \mathrm{mg} / \mathrm{dL}$. It is notable that when the baseline serum creatinine is high, there is more inherent variability in the serum creatinine measurement; thus, patients with CKD have a higher risk of being misclassified as having AKI. ${ }^{17}$ Although the KDIGO definition for AKI is commonly used in research settings, components of this definition have not been well validated, and it is not widely used in clinical practice. Other renal professional societies still recommend an individualized approach to the diagnosis of $\mathrm{AKI}$, taking into 
TABLE 1. Serum Creatinine and Urine Output Criteria for Acute Kidney Injury

\begin{tabular}{|c|c|c|c|c|c|c|}
\hline & \multicolumn{5}{|c|}{ Serum Creatinine Criteria } & \multirow{2}{*}{$\begin{array}{l}\text { Urine Output Criteria } \\
\text { (Common to All) }\end{array}$} \\
\hline & \multicolumn{2}{|l|}{ RIFLE } & \multicolumn{2}{|c|}{ AKIN ${ }^{b}$} & KDIGO & \\
\hline Definition & \multirow{2}{*}{\multicolumn{2}{|c|}{$\begin{array}{l}\geq 50 \% \text { increase from baseline or } \\
\text { GFR decline }>25 \% \text { over } 7 \text { days }{ }^{\mathrm{a}}\end{array}$}} & \multirow{2}{*}{\multicolumn{2}{|c|}{$\begin{array}{l}\text { Increase } \geq 0.3 \mathrm{mg} / \mathrm{dL} \text { or } \\
\geq 50 \% \text { increase from baseline over } \\
48 \text { hours }\end{array}$}} & \multirow{2}{*}{$\begin{array}{l}\text { Increase } \geq 0.3 \mathrm{mg} / \mathrm{dL} \text { over } 48 \text { hours or } \\
\geq 50 \% \text { increase from baseline over } 7 \text { days }\end{array}$} & $<0.5 \mathrm{~mL} / \mathrm{kg} /$ hour for 6 hours \\
\hline & & & & & & \\
\hline \multirow[t]{10}{*}{ Staging } & \multirow[t]{2}{*}{ Risk } & $\geq 50 \%$ increase or & \multirow[t]{2}{*}{1} & Increase $\geq 0.3 \mathrm{mg} / \mathrm{dL}$ or & \multirow{2}{*}{$\begin{array}{l}1 \quad \text { Increase } \geq 0.3 \mathrm{mg} / \mathrm{dL} \text { or } \\
\geq 50 \% \text { increase }\end{array}$} & \multirow[t]{2}{*}{$<0.5 \mathrm{~mL} / \mathrm{kg} / \mathrm{hour}$ for 6 hours } \\
\hline & & GFR decline $>25 \%$ & & $\geq 50 \%$ increase & & \\
\hline & \multirow[t]{2}{*}{ Injury } & $\geq 100 \%$ increase or & \multirow[t]{2}{*}{2} & $\geq 100 \%$ increase & \multirow[t]{2}{*}{$2 \geq 100 \%$ increase } & \multirow[t]{2}{*}{$<0.5 \mathrm{~mL} / \mathrm{kg} /$ hour for 12 hours } \\
\hline & & GFR decline $>50 \%$ & & & & \\
\hline & \multirow[t]{4}{*}{ Failure } & $\geq 200 \%$ increase or & \multirow[t]{4}{*}{3} & $\geq 200 \%$ increase or & \multirow{4}{*}{$\begin{array}{l}3 \geq 200 \% \text { increase or } \\
\mathrm{sCr} \geq 4 \mathrm{mg} / \mathrm{dL}^{c} \text { or } \\
\text { RRT }\end{array}$} & \multirow{4}{*}{$\begin{array}{l}<0.3 \mathrm{~mL} / \mathrm{kg} / \text { hour for } 24 \text { hours or } \\
\text { Anuria for } 12 \text { hours }\end{array}$} \\
\hline & & GFR decline $>75 \%$ or & & \multirow{3}{*}{$\begin{array}{l}\mathrm{sCr} \geq 4 \mathrm{mg} / \mathrm{dL} \text { with acute rise } \\
\geq 0.5 \mathrm{mg} / \mathrm{dL} \text { or } \\
\text { RRT }\end{array}$} & & \\
\hline & & \multirow{2}{*}{$\begin{array}{l}\mathrm{s} C r \geq 4 \mathrm{mg} / \mathrm{dL} \text { with acute } \\
\text { rise } \geq 0.5 \mathrm{mg} / \mathrm{dL}\end{array}$} & & & & \\
\hline & & & & & & \\
\hline & Loss & RRT for $\geq 4$ weeks & & & & \\
\hline & $\begin{array}{l}\text { End-stage kidney } \\
\text { disease }\end{array}$ & RRT for $\geq 3$ months & & & & \\
\hline \multirow[t]{3}{*}{ Strengths } & \multirow{3}{*}{\multicolumn{2}{|c|}{$\begin{array}{l}\text { Validated criteria and staging system; higher } \\
\text { stages are associated with higher mortality } \\
\text { and RRT dependence }\end{array}$}} & \multirow{2}{*}{\multicolumn{2}{|c|}{$\begin{array}{l}\text { Validated criteria and staging } \\
\text { system; higher stages are } \\
\text { associated with higher mortality } \\
\text { and RRT dependence } \\
\text { Incorporates smaller changes in } \\
\text { serum creatinine }\end{array}$}} & \multirow[t]{3}{*}{$\begin{array}{l}\text { Uses components of previously validated criteria from } \\
\text { RIFLE and AKIN }\end{array}$} & \multirow[t]{3}{*}{$\begin{array}{l}\text { Urine output may be more sensitive } \\
\text { than serum creatinine }\end{array}$} \\
\hline & & & & & & \\
\hline & & & $\begin{array}{l}\text { Less } \\
\text { bas }\end{array}$ & $\begin{array}{l}\text { reliant on knowledge of } \\
\text { line creatinine }\end{array}$ & & \\
\hline \multirow[t]{5}{*}{ Weaknesses } & \multicolumn{2}{|c|}{$\begin{array}{l}\text { Creatinine-based measure is limited in certain } \\
\text { populations (catabolic states or sarcopenia) }\end{array}$} & \multirow{2}{*}{\multicolumn{2}{|c|}{$\begin{array}{l}\text { Creatinine-based measure is } \\
\text { limited in certain populations } \\
\text { (catabolic states or sarcopenia) }\end{array}$}} & \multirow{5}{*}{$\begin{array}{l}\text { Creatinine-based measure is limited in certain populations } \\
\text { (catabolic states or sarcopenia) } \\
\text { Small changes in serum creatinine in patients with CKD } \\
\text { may result in misclassification }\end{array}$} & \multirow{5}{*}{$\begin{array}{l}\text { Urine output criteria are less well } \\
\text { validated than creatinine-based } \\
\text { criteria for acute kidney injury }\end{array}$} \\
\hline & \multicolumn{2}{|c|}{ Need to know baseline creatinine or GFR } & & & & \\
\hline & $\begin{array}{l}\text { Assumption of ba } \\
\text { misclassification }\end{array}$ & eline GFR results in & \multicolumn{2}{|c|}{$\begin{array}{l}\text { Small changes in serum creatinine } \\
\text { in patients with CKD may result in } \\
\text { misclassification }\end{array}$} & & \\
\hline & $\begin{array}{l}\text { Serum creatinine } \\
\text { with GFR change }\end{array}$ & $\begin{array}{l}\text { nange does not correlate } \\
\text { rom the same stage }\end{array}$ & $\begin{array}{l}\text { Nee } \\
\text { mea }\end{array}$ & $\begin{array}{l}\text { d two separate creatinine } \\
\text { sures within } 48 \text { hours }\end{array}$ & & \\
\hline & $\begin{array}{l}\text { Creatinine and uri } \\
\text { same stage do no }\end{array}$ & $\begin{array}{l}\text { e output criteria from the } \\
\text { have similar mortality risk }\end{array}$ & & & & \\
\hline
\end{tabular}

alf baseline renal function is unknown and there is no known history of CKD, then the baseline GFR of $75 \mathrm{~mL} / \mathrm{min} / 1.73 \mathrm{~m}^{2}$ is used.

${ }^{b}$ Apply diagnostic criteria after adequate fluid resuscitation. Rule out urinary tract obstruction before making the diagnosis based on urine output criteria alone.

cMust also fulfill the creatinine-based definition of acute kidney injury (creatinine $\geq 0.3 \mathrm{mg} / \mathrm{dL}$ over 48 hours or $\geq 50 \%$ increase from baseline over 7 days).

Abbreviations: AKIN, Acute Kidney Injury Network ${ }^{14}$; CKD, chronic kidney disease; GFR, glomerular filtration rate; KDIGO, Kidney Disease: Improving Global Outcomes ${ }^{15}$; RIFLE, Risk, Injury,

Failure, Loss, End-stage kidney disease ${ }^{13}$; RRT, renal replacement therapy; $\mathrm{SCr}$, serum creatinine.

account other factors such as trajectories in kidney function, fluid balance, electrolyte abnormalities, comorbid conditions, and clinical context. ${ }^{18,19}$ While we endorse the KDIGO approach to the categorization of AKI severity, in practice, a more patient-centered approach is generally required to guide the optimal approach to determining the etiology of AKI and guiding management.

\section{GENERAL MANAGEMENT OF ACUTE KIDNEY INJURY}

All patients with $A K I$ should have close monitoring of their serum creatinine and urine output. Noninvasive diagnostic studies (urine microscopy, postvoid residual, and renal ultrasound) should be considered based on the clinical scenario. General management strategies include treatment of the reversible causes of $\mathrm{AKI}$ and optimization of volume status, hemodynamics, and nutritional status (Table 2).

\section{Reversible Causes of Acute Kidney Injury}

The first step in the treatment of $A K I$ is to identify and treat readily reversible causes of $\mathrm{AKI}$ such as volume depletion, hypotension, infection, and urinary obstruction. Nephrotoxins should be avoided and all medications should be reviewed and adjusted for kidney function, particularly those that may affect mental status. Avoid opiates with noxious or active metabolites, including meperidine and morphine. Instead, hydro- 
TABLE 2. Summary of Management Considerations in Acute Kidney Injury

\begin{tabular}{|c|c|c|}
\hline AKI Management & Comments & Recommendations \\
\hline \multirow[t]{3}{*}{$\begin{array}{l}\text { Identify and treat reversible causes of Acute } \\
\text { Kidney Injury }\end{array}$} & $\begin{array}{l}\text { Obtain detailed history and examination. } \\
\text { Review all medications. }\end{array}$ & $\begin{array}{l}\text { Identify and treat hypovolemia, hypotension, infection, and urinary } \\
\text { obstruction. }\end{array}$ \\
\hline & \multirow{2}{*}{ Review all medications. } & Avoid nephrotoxins. \\
\hline & & Renally dose medications. \\
\hline \multirow[t]{3}{*}{ Intravenous fluids } & $\begin{array}{l}\text { For most patients, albumin has an unproven benefit compared } \\
\text { with crystalloid solutions. }\end{array}$ & \multirow{3}{*}{$\begin{array}{l}\text { Volume resuscitate with crystalloid solutions. Consider balanced crystalloid } \\
\text { solutions to avoid severe hyperchloremia and acidosis in large volume } \\
\text { (>2 L) resuscitation, particularly in critically ill patients. }\end{array}$} \\
\hline & Hydroxyethyl starch is not recommended. & \\
\hline & $\begin{array}{l}\text { Balanced crystalloid solutions reduce the risk of severe hyperchloremia and } \\
\text { acidosis and may be associated with a lower risk of AKI. }\end{array}$ & \\
\hline \multirow[t]{2}{*}{ Diuretics } & Diuretics do not directly affect AKI recovery or survival. & \multirow[t]{2}{*}{ Only use diuretics as needed for volume overload. } \\
\hline & Patients with AKI may need high doses of diuretics to respond. & \\
\hline \multirow[t]{2}{*}{ Nutrition } & Patients in catabolic states may have high protein requirements. & \multirow{2}{*}{$\begin{array}{l}\text { Nutrition consultation is recommended to ensure adequate, but not } \\
\text { excessive, protein intake. }\end{array}$} \\
\hline & $\begin{array}{l}\text { Excess protein intake may contribute to azotemia out of proportion } \\
\text { to renal failure. }\end{array}$ & \\
\hline \multirow[t]{2}{*}{ Renal replacement therapy } & Optimal timing of renal replacement therapy is not known. & \multirow{2}{*}{$\begin{array}{l}\text { Medical management of fluid and electrolyte abnormalities in nonoliguric } \\
\text { patients with AKI should be attempted while assessing renal replacement } \\
\text { therapy needs. }\end{array}$} \\
\hline & $\begin{array}{l}\text { No evidence for mortality benefit of continuous renal replacement therapy } \\
\text { over intermittent hemodialysis. }\end{array}$ & \\
\hline
\end{tabular}

morphone, fentanyl, and methadone are preferred in patients with AKI. Other commonly used medications that require dose adjustment include gabapentin, baclofen, metoclopramide, $\mathrm{H} 2$ antagonists, many commonly prescribed antibiotics (penicillins, most cephalosporins, carbapenems, quinolones, and sulfa drugs), many hypoglycemic agents, and insulin. For patients on RRT, dosing is dependent on dialysis modality. Consultation with a hospital pharmacist is recommended when RRT modalities are initiated or changed.

\section{Intravenous Fluids}

Patients with AKI should have their volume status assessed and receive adequate resuscitation with intravenous fluids to promote renal perfusion. However, the optimal type and volume of fluid to give in AKI remains controversial. Colloid-containing solutions are theoretically confined to the intravascular space and should pose a lower risk for pulmonary edema compared with crystalloids. However, these solutions are costly, are not associated with any meaningful benefit, ${ }^{20-22}$ and may even be associated with potential harm. ${ }^{22-27}$

The most commonly used colloid worldwide is hydroxyethyl starch (HES). Its potential adverse effects include anaphylactoid reactions, coagulopathy, and AKI. HES is cleared by the kidneys and can cause osmotic nephrosis, a form of AKI characterized by vacuole formation and proximal renal tubular damage. ${ }^{28}$ Randomized controlled trials have shown an increased risk of AKI, RRT use, and mortality in critically ill patients who were resuscitated with HES. 22,26,27 HES is not currently recommended in patients who are critically ill or have impaired kidney function and sepsis guidelines advise against its use. ${ }^{29}$

In the United States, albumin is the most common colloid-containing solution used for intravascular volume resuscitation. Albumin has been shown to be safe for volume resusci- tation in critically ill patients, ${ }^{20}$ but there is no proven advantage to using albumin over saline with respect to mortality, length of hospital stay, duration of mechanical ventilation, duration of RRT, or number of organ systems failure. ${ }^{20,21}$ Furthermore, albumin may be harmful in certain patient populations. In patients with traumatic brain injury, albumin resuscitation is associated with higher mean intracranial pressure ${ }^{23}$ and long-term mortality. ${ }^{24}$ In a retrospective study of patients undergoing cardiac surgery, albumin administration was associated with more than twice the risk of AKI compared with crystalloids. ${ }^{25}$ In contrast, in patients with cirrhosis, intravenous albumin lowers the rate of $\mathrm{AKI}$ when administered in the setting of a large volume paracentesis ${ }^{30}$ or spontaneous bacterial peritonitis. ${ }^{31}$ Outside of these narrow settings, current evidence does not support the use of intravenous albumin to prevent $A K I$ and we would not endorse the use of intravenous albumin as a part of the treatment paradigm for established AKI.

Many renal and critical care guidelines recommend initial fluid resuscitation with isotonic crystalloids except in specific circumstances (ie, hemorrhagic shock), with consideration of albumin in select cases (ie, severe sepsis or cirrhosis). ${ }^{16,18,19,29}$ That stated, the optimal type of crystalloid solution that should be used in resuscitation remains unclear. Because of its low cost, normal $(0.9 \%)$ saline is the most commonly used solution, but it can result in hyperchloremic metabolic acidosis, which can cause renal vasoconstriction and may be associated with mortality in critically ill patients. ${ }^{32}$ A prospective study found that administration of chloride-liberal fluids (including normal saline) to critically ill patients was associated with nearly twice the risk of $A K I$ and RRT use compared with chloride-restrictive fluids, ${ }^{33}$ but a subsequent trial found no difference in AKI or mortality among patients receiving saline versus a balanced crystalloid (Plasma-Lyte 148). ${ }^{34}$ A recent pair of large, random- 
TABLE 3. Potential Indications for Renal Replacement Therapy and Medical Treatment Alternatives

\begin{tabular}{|c|c|c|}
\hline & Medical Treatment Alternatives to RRT & Comments \\
\hline Volume Overload & Diuretics & RRT may be considered in nonoliguric patients with pulmonary edema or severe heart failure. \\
\hline \multirow[t]{5}{*}{ Hyperkalemia } & Insulin/glucose & Binding resins are avoided in patients with recent abdominal surgery. \\
\hline & Beta 2 agonists & \\
\hline & Sodium bicarbonate & \\
\hline & Diuretics & \\
\hline & Binding resins & \\
\hline \multirow[t]{2}{*}{ Acidemia } & Sodium bicarbonate & Generally not needed if $\mathrm{pH}>7.20$, but there is no consensus regarding when to start RRT for acidemia. \\
\hline & Balanced crystalloid solutions & \\
\hline Uremic Symptoms or Complications & Not applicable & RRT is generally started before severe complications (pericarditis and seizures) are observed. \\
\hline
\end{tabular}

ized control trials compared outcomes in patients at a single center who were resuscitated with normal saline versus balanced crystalloid solutions (Lactated Ringer's or Plasma-Lyte A). ${ }^{35,36}$ In critically ill patients, the use of balanced crystalloid solutions was associated with a lower risk of the composite outcome of mortality, new RRT, or persistent kidney impairment, but there were no differences in any of the individual components of the composite outcome. ${ }^{35}$ In noncritically ill patients, there were no differences in the number of hospital-free days based on the type of crystalloid solution used. ${ }^{36}$ In the absence of compelling evidence for using balanced crystalloid solutions, we continue to use normal saline for initial fluid resuscitation, but to avoid severe hyperchloremia and acidosis, we will consider switching to a balanced solution (Lactated Ringer's, Plasma-Lyte, or Normosol) for large volume resuscitation (>2 L), particularly in critically ill patients.

\section{Diuretics}

As above, volume status is a key component in the management of patients with $\mathrm{AKI}$. In patients with $\mathrm{AKI}$ and hypervolemia, loop diuretics are often given prior to the initiation of RRT. Loop diuretics act on the sodium-potassium-chloride cotransporters in the thick ascending limb of the loop of Henle to increase urinary losses of these ions and urine volume. Loop diuretics are dose-dependent, and often, higher doses are needed (eg, furosemide $100 \mathrm{mg}$ intravenous dose) in patients with $\mathrm{AKI}$, since the diuretic effect depends on the proximal tubular secretion of the drug into the urine. The role of diuretics in $\mathrm{AKI}$ is controversial and some observational data suggest an increased mortality risk with diuretic use in patients with AKI. ${ }^{37}$ In critically ill patients with acute lung injury, diuretic use improved survival, which was attributed to better control of volume overload. ${ }^{38}$ But, a meta-analysis of 11 randomized controlled trials failed to demonstrate that diuretics directly improved survival or recovery of AKI. ${ }^{39}$ Moreover, randomized controlled trials found that diuretics given to a patient with $\mathrm{AKI}$ requiring RRT did not improve recovery of kidney function. ${ }^{40,41}$ The KDIGO guidelines recommend that diuretics should not be routinely used for $\mathrm{AKI}$ except in the management of volume overload. ${ }^{16}$

\section{Nutritional Targets in Acute Kidney Injury}

Critically ill patients have high protein catabolic rates, which put them at increased risk for malnutrition, which in turn is associated with mortality. Patients who receive continuous RRT (CRRT) may lose 5-10 $\mathrm{g}$ of protein and 10-15 $\mathrm{g}$ of amino acids daily, and these patients may have protein requirements that are twice the usual recommended daily protein intake. ${ }^{16}$ But excess protein administration can result in high urea generation and azotemia unrelated to the patient's kidney function. Blood urea nitrogen may also be disproportionately elevated in conditions where tubular reabsorption of urea is increased, such as in volume depletion, diuretic use, corticosteroid use, and gastrointestinal bleeding. Interpretation of blood urea nitrogen results must be made in the appropriate clinical context, with recognition that azotemia alone may not be a good surrogate marker of the patient's underlying kidney function. We recommend dietary consultation in critically ill patients with $\mathrm{AKI}$ to ensure that adequate, but not excessive, protein is administered.

\section{RENAL REPLACEMENT THERAPY IN ACUTE KIDNEY INJURY}

In patients with AKI, RRT is initiated for control of volume overload, electrolyte abnormalities, acidemia, or uremic symptoms or complications that are refractory to medical management (Table 3). In a nonoliguric patient, fluid and electrolyte abnormalities can oftentimes be managed medically. Patients with oligoanuria (generally defined as urine output less than 400 $\mathrm{mL} /$ day or $<20 \mathrm{~mL} /$ hour), however, require nephrology evaluation for consideration of RRT. Early nephrology consultation (within 48 hours of AKI diagnosis) may be associated with lower dialysis dependence and mortality in critically ill patients with AKI. ${ }^{42}$ The decision to initiate dialysis is individualized based on the patient's comorbid conditions, urine output, and trajectory of kidney function. 
TABLE 4. Comparison of Randomized Trials of Early Versus Late Dialysis in Patients with AKI

\begin{tabular}{|c|c|c|c|c|}
\hline & ELAIN & AKIKI & IDEAL-ICU & STARRT-AKI \\
\hline Study design & Randomized controlled trial & Randomized controlled trial & Randomized controlled trial & Randomized controlled trial \\
\hline \multirow[t]{2}{*}{ Country/Setting } & Germany & France & France & 15 countries, \\
\hline & Single center ICU & $31 \mathrm{ICUs}$ & $27 \mathrm{ICUs}$ & $111 \mathrm{ICUs}$ \\
\hline \multirow[t]{2}{*}{ Patient population } & $\begin{array}{l}231 \text { patients with critical illness and at least } \\
\text { stage } 2 \mathrm{AKI}\end{array}$ & $\begin{array}{l}620 \text { patients with critical illness } \\
\text { and stage } 3 \mathrm{AKI}\end{array}$ & $\begin{array}{l}864 \text { patients with septic shock and AKI } \\
\text { (RIFLE stage failure) }\end{array}$ & 2,866 patients with severe AKI \\
\hline & Mostly surgical ICU (47\% cardiac surgery) & Mostly medical ICU & & \\
\hline Intervention (early dialysis initiation) & Within 8 hours of stage 2 AKI & Within 6 hours of stage 3 AKI & Within 12 hours after diagnosis of AKI & $\begin{array}{l}\text { Within } 12 \text { hours of study } \\
\text { eligibility }\end{array}$ \\
\hline Control (delayed dialysis initiation) & Within 12 hours of stage $3 \mathrm{AKI}$ & Standard indications for RRT & At least 48 hours after diagnosis of AKI & $>12$ hours of study eligibility \\
\hline Dialysis modality & Continuous venovenous hemodiafiltration & $\begin{array}{l}\text { Provider discretion } \\
\text { ( } 47 \% \text { intermittent RRT only) }\end{array}$ & Provider discretion & Provider discretion \\
\hline Primary outcome & Mortality at 90 days & Mortality at 60 days & Mortality at 90 days & Mortality at 90 days \\
\hline \multirow[t]{4}{*}{ Results } & 20-hour difference between groups & 55-hour difference between groups & To be determined & To be determined \\
\hline & $\begin{array}{l}\text { Lower mortality in early dialysis group } \\
\text { (HR } 0.66,95 \% \mathrm{Cl} 0.45-0.97)\end{array}$ & $\begin{array}{l}\text { No difference in mortality between } \\
\text { groups }(P=.79)\end{array}$ & & \\
\hline & \multirow{2}{*}{$\begin{array}{l}\text { Greater renal recovery at } 90 \text { days, shorter } \\
\text { duration of RRT, and shorter hospital length } \\
\text { of stay with early dialysis }\end{array}$} & $\begin{array}{l}49 \% \text { of the delayed dialysis group } \\
\text { did not get dialysis }\end{array}$ & & \\
\hline & & $\begin{array}{l}\text { A higher rate of catheter-related } \\
\text { bloodstream infections in the early } \\
\text { dialysis group (10\% vs } 5 \%, P=.03)\end{array}$ & & \\
\hline
\end{tabular}

Abbreviations: AKI, acute kidney injury; AKIKI, Artificial Kidney Initiation in Kidney Injury Study; ELAIN, Early vs Late Initiation of Renal Replacement Therapy in Critically III Patients with AKI; ICU, intensive care unit; IDEAL-ICU, Initiation of Dialysis Early Versus Delayed in ICU; RIFLE, Risk, Injury, Failure, Loss, and End-stage kidney disease; RRT, renal replacement therapy; STARRT-AKI, Standard versus Accelerated Initiation of RRT in AKI.

\section{Timing of Renal Replacement Therapy}

The optimal timing of dialysis initiation in patients with AKI is not known. Theoretically, earlier initiation of dialysis could allow for better volume and electrolyte control and prevent the development of more serious complications of kidney failure such as uremic seizures, encephalopathy, and pericarditis. However, RRT is associated with its own risks and earlier initiation may expose the patient to unnecessary procedures and complications that might delay renal recovery. A meta-analysis of predominantly observational data found that earlier initiation of RRT in AKI was associated with lower 28-day mortality, greater renal recovery, decreased duration of RRT, and decreased ICU length of stay. ${ }^{43}$ Subsequently, two prospective trials reported conflicting results regarding associations between dialysis timing and outcomes in patients with severe AKI (Table 4). ${ }^{44,45}$

The Early vs Late Initiation of Renal Replacement Therapy in Critically III Patients with Acute Kidney Injury (ELAIN) was a prospective, single-center randomized trial in Germany of 231 critically ill, predominantly surgical ICU patients (about half postcardiac surgery) with at least KDIGO stage 2 AKI. ${ }^{44}$ Patients were randomized to early (within eight hours of developing KDIGO stage $2 \mathrm{AKI}$ ) or delayed (within 12 hours of developing KDIGO stage $3 \mathrm{AKI}$ ) RRT initiation; patients in the early RRT group initiated dialysis on average 20 hours earlier than the patients in the late group. All patients were treated with continuous venovenous hemodiafiltration. Early RRT ini- tiation was associated with a 34\% lower risk of mortality at 90 days, shorter hospital length of stay, and shorter RRT duration compared with delayed RRT initiation. There was no difference between groups in dialysis dependence at 90 days, but there was a lower risk of dialysis dependence at one year. ${ }^{46}$

The Artificial Kidney Initiation in Kidney Injury Study (AKIKI) ${ }^{45}$ was a prospective, multicenter randomized trial in France that compared early versus delayed strategies of RRT initiation in 620 critically ill, mostly medical ICU patients with severe AKI (KDIGO stage 3). The median time between randomization and RRT initiation was two hours for the early and 57 hours for the delayed strategy groups. There were no differences between groups in length of hospital or ICU stay, vasopressor use, dialysis dependence, or 60-day survival. The early strategy group had a higher incidence of catheter-related bloodstream infections (10\% vs $5 \%$ ) and hypophosphatemia (22\% vs $15 \%$ ) compared with that of the delayed strategy group. Patients in the delayed strategy group regained normal urine output sooner than in the early strategy group. Approximately half of the patients in the delayed strategy group avoided RRT altogether. The authors of AKIKI concluded that there was no benefit to the early strategy of RRT in critically ill patients with severe $A K I$, and a delayed strategy of RRT initiation may avoid unnecessary RRT and reduce catheter-related infectious complications.

How can we interpret these discrepant results? Although ELAIN found a benefit to earlier RRT initiation in AKI, it has lim- 
ited generalizability to medical ICU patients, who have higher mortality and whose outcomes might be less affected by dialysis timing. Patients in ELAIN had a high prevalence of congestive heart failure and CKD; it is possible that select patient populations may derive greater benefit from earlier RRT initiation. Although both ELAIN and AKIKI used the standardized criteria for RRT initiation, neither study could incorporate important clinical factors such as trajectory of kidney function, comorbid conditions, or symptoms, which play a significant role in the decision-making process in real-world clinical practice. Additional large-scale, multicenter trials are needed to guide the timing of RRT in critically ill patients with AKI. The Initiation of Dialysis Early Versus Delayed in the ICU (IDEAL-ICU) ${ }^{47}$ and Standard versus Accelerated Initiation of RRT in Acute Kidney Injury (STARRT-AKI) ${ }^{48}$ studies are currently underway and hope to provide clearer guidance regarding the optimal timing of RRT initiation in AKI (Table 4). Until further evidence is available, experts recommend taking into consideration the trajectory of kidney disease, concurrent organ dysfunction, and expected need for fluid and solute control when making decisions regarding RRT initiation in AKI. ${ }^{16}$

\section{DIALYSIS MODALITIES IN ACUTE KIDNEY INJURY}

When RRT is required in patients with $\mathrm{AKI}$, the dialysis modality is often determined by local availability. CRRT and sustained low-efficiency dialysis (SLED) are thought to be better tolerated than intermittent hemodialysis in hemodynamically unstable patients, although a randomized controlled trial could not demonstrate a survival difference between these modalities. ${ }^{49}$ In general, in settings where CRRT or SLED is available, these modalities are favored for patients with hemodynamic instability, but practice patterns vary widely.

\section{CONCLUSION}

Among hospitalized patients, AKI is common and associated with a higher risk of mortality. Although serum creatinine and urine output criteria are used to define AKI, other clinical factors (comorbid conditions, volume status, and trajectory of kidney function decline) can inform the assessment and management of patients with AKI. General strategies for AKI management include treatment of reversible conditions, optimization of volume status, hemodynamics, and nutritional status. The optimal timing of RRT in critically ill patients with AKI is not known, with unclear mortality benefit of earlier dialysis initiation. Two large-scale randomized controlled trials regarding early versus delayed dialysis timing in AKI are currently underway and will hopefully provide clarity in the near future.

Disclosures: Dr. Yu and Dr. Kamal have nothing to disclose. Dr. Chertow is an advisor to DURECT Corporation, a biopharmaceutical company.

\section{References}

1. Wang HE, Muntner P, Chertow GM, Warnock DG. Acute kidney injury and mortality in hospitalized patients. Am J Nephrol. 2012;35(4):349-355.

2. Uchino S, Bellomo R, Goldsmith D, Bates S, Ronco C. An assessment of the RIFLE criteria for acute renal failure in hospitalized patients. Crit Care Med. 2006;34(7):1913-1917

3. Hoste EA, Bagshaw SM, Bellomo R, et al. Epidemiology of acute kidney injury in critically ill patients: the multinational AKI-EPI study. Intensive Care Med. 2015;41(8):1411-1423. doi: 10.1007/s00134-015-3934-7.

4. Wald R, McArthur E, Adhikari NKJ, et al. Changing incidence and outcomes following dialysis-requiring acute kidney injury among critically ill adults: a population-based cohort study. Am J Kidney Dis. 2015;65(6):870-877. doi: https://doi.org/10.1053/j.ajkd.2014.10.017.

5. Siew ED, Davenport A. The growth of acute kidney injury: a rising tide or just closer attention to detail? Kidney Int. 2015;87(1):46-61. doi: 10.1038/ ki.2014.293.

6. Lenihan CR, Montez-Rath ME, Mora Mangano CT, Chertow GM, Winkelmayer WC. Trends in acute kidney injury, associated use of dialysis, and mortality after cardiac surgery, 1999 to 2008. Ann Thorac Surg. 2013;95(1):20-28. doi: 10.1016/j.athoracsur.2012.05.131.

7. Chertow GM, Burdick E, Honour M, Bonventre JV, Bates DW. Acute kidney injury, mortality, length of stay, and costs in hospitalized patients. J Am Soc Nephrol. 2005;16(11):3365-3370. doi: 10.1681/ASN.2004090740.

8. Ricci Z, Cruz D, Ronco C. The RIFLE criteria and mortality in acute kidney injury: a systematic review. Kidney Int. 2008;73(5):538-546. doi: https://doi. org/10.1038/sj.ki.5002743.

9. Coca SG, Singanamala S, Parikh CR. Chronic kidney disease after acute kidney injury: a systematic review and meta-analysis. Kidney Int. 2012;81(5):442448. doi: 10.1038/ki.2011.379.

10. Ali T, Khan I, Simpson W, et al. Incidence and outcomes in acute kidney injury: a comprehensive population-based study. J Am Soc Nephrol. 2007;18(4):1292-1298. doi: 10.1681/ASN.2006070756.

11. Koulouridis I, Price LL, Madias NE, Jaber BL. Hospital-acquired acute kid ney injury and hospital readmission: a cohort study. Am J Kidney Dis. 2015;65(2):275-282. doi: https://doi.org/10.1053/j.ajkd.2014.08.024.

12. Bucaloiu ID, Kirchner HL, Norfolk ER, Hartle JE, 2nd, Perkins RM. Increased risk of death and de novo chronic kidney disease following reversible acute kidney

injury. Kidney Int. 2012;81(5):477-485. doi: https://doi.org/10.1038/ki.2011.405.

13. Cooper CM, Fenves AZ. Before you call renal: acute kidney injury for hospitalists. J Hosp Med. 2015;10(6):403-408. doi: 10.1002/jhm.2325.

14. Bellomo R, Ronco C, Kellum JA, Mehta RL, Palevsky P, Workgroup A. Acute renal failure - definition, outcome measures, animal models, fluid therapy and information technology needs: the Second International Consensus Conference of the Acute Dialysis Quality Initiative (ADQI) Group. Crit Care. 2004;8(4):R204-R212. doi: 10.1186/cc2872.

15. Mehta RL, Kellum JA, Shah SV, et al. Acute kidney injury network: report of an initiative to improve outcomes in acute kidney injury. Crit Care. 2007;11(2): R31. doi: 10.1186/cc5713.

16. Kidney Disease: Improving Global Outcomes (KDIGO) Acute Kidney Injury Work Group. KDIGO clinical practice guideline for acute kidney injury. Kidney Int Suppl. 2012;2(1):1-138. doi: 10.1038/kisup.2012.2.

17. Lin J, Fernandez $H$, Shashaty MG, et al. False-positive rate of $A K I$ using consensus creatinine-based criteria. Clin J Am Soc Nephrol. 2015;10(10):17231731. doi: 10.2215/CJN.02430315.

18. Palevsky PM, Liu KD, Brophy PD, et al. KDOQI US commentary on the 2012 KDIGO clinical practice guideline for acute kidney injury. Am J Kidney Dis. 2013;61(5):649-672. doi: 10.1053/j.ajkd.2013.02.349.

19. James M, Bouchard J, Ho J, et al. Canadian Society of Nephrology commentary on the $2012 \mathrm{KDIGO}$ clinical practice guideline for acute kidney injury. Am J Kidney Dis. 2013;61(5):673-685. doi: 10.1053/j.ajkd.2013.02.350.

20. Finfer S, Bellomo R, Boyce N, et al. A comparison of albumin and saline for fluid resuscitation in the intensive care unit. N Engl J Med. 2004;350(22):22472256. doi: 10.1056/NEJMoa040232.

21. Caironi $P$, Tognoni $G$, Masson $S$, et al. Albumin replacement in patients with severe sepsis or septic shock. N Engl J Med. 2014;370(15):1412-1421. doi: 10.1056/NEJMoa1305727.

22. Myburgh JA, Finfer S, Bellomo R, et al. Hydroxyethyl starch or saline for fluid resuscitation in intensive care. N Engl J Med. 2012;367(20):1901-1911. doi: 10.1056/NEJMoa1209759.

23. Cooper DJ, Myburgh J, Heritier S, et al. Albumin resuscitation for traumatic brain injury: is intracranial hypertension the cause of increased mortality? J Neurotrauma. 2013;30(7):512-518. doi: 10.1089/neu.2012.2573.

24. Myburgh J, Cooper J, Finfer S, et al. Saline or albumin for fluid resuscitation 
in patients with traumatic brain injury. N Engl J Med. 2007;357(9):874-884 doi: 10.1056/NEJMoa067514.

25. Frenette AJ, Bouchard J, Bernier P, et al. Albumin administration is associated with acute kidney injury in cardiac surgery: a propensity score analysis. Crit Care. 2014;18(6):602. doi: 10.1186/s13054-014-0602-1.

26. Schortgen F, Lacherade JC, Bruneel F, et al. Effects of hydroxyethyl starch and gelatin on renal function in severe sepsis: a multicentre randomised study. Lancet. 2001;357(9260):911-916. doi: https://doi.org/10.1016/S01406736(00)04211-2

27. Perner A, Haase N, Guttormsen AB, et al. Hydroxyethyl starch 130/0.42 versus Ringer's acetate in severe sepsis. N Engl J Med. 2012;367(2):124-134. doi: 10.1056/NEJMoa1204242.

28. Dickenmann M, Oettl T, Mihatsch MJ. Osmotic nephrosis: acute kidney injury with accumulation of proximal tubular lysosomes due to administration of exogenous solutes. Am J Kidney Dis. 2008;51(3):491-503. doi: 10.1053/j. ajkd.2007.10.044

29. Dellinger RP, Levy MM, Rhodes A, et al. Surviving sepsis campaign: international guidelines for management of severe sepsis and septic shock: 2012. Crit Care Med. 2013:41(2):580-637. doi: 10.1097/CCM.0b013e31827e83af.

30. Bernardi M, Caraceni P, Navickis RJ, Wilkes MM. Albumin infusion in patients undergoing large-volume paracentesis: a meta-analysis of randomized trials. Hepatology. 2012;55(4):1172-1181. doi: 10.1002/hep.24786.

31. Sort $P$, Navasa $M$, Arroyo $V$, et al. Effect of intravenous albumin on re nal impairment and mortality in patients with cirrhosis and spontaneous bacterial peritonitis. N Engl J Med. 1999;341(6):403-409. doi: 10.1056/ NEJM199908053410603

32. Boniatti MM, Cardoso PRC, Castilho RK, Vieira SRR. Is hyperchloremia associated with mortality in critically ill patients? A prospective cohort study. J Crit Care. 2011;26(2):175-179. doi: 10.1016/j.jcrc.2010.04.013

33. Yunos NM, Bellomo R, Hegarty C, Story D, Ho L, Bailey M. Association between a chloride-liberal vs chloride-restrictive intravenous fluid administration strategy and kidney injury in critically ill adults. JAMA. 2012;308(15):15661572. doi: 10.1001/jama.2012.13356.

34. Young P, Bailey M, Beasley R, et al. Effect of a buffered crystalloid solution vs saline on acute kidney injury among patients in the intensive care unit: the SPLIT randomized clinical trial. JAMA. 2015;314(16):1701-1710. doi: 10.1001/ jama.2015.12334.

35. Semler MW, Self WH, Wanderer JP, et al. Balanced crystalloids versus saline in critically ill adults. N Engl J Med. 2018;378(9):829-839. doi: 10.1056/NEJMoa1711584.

36. Self WH, Semler MW, Wanderer JP, et al. Balanced crystalloids versus saline in noncritically ill adults. N Engl J Med. 2018;378(9):819-828. doi: 10.1056/ NEJMoa1711586.

37. Mehta RL, Pascual MT, Soroko S, Chertow GM, Group PS. Diuretics, mortality, and nonrecovery of renal function in acute renal failure. JAMA
2002;288(20):2547-2553. doi:10.1001/jama.288.20.2547

38. Grams ME, Estrella MM, Coresh J, et al. Fluid balance, diuretic use, and mortality in acute kidney injury. Clin J Am Soc Nephrol. 2011;6(5):966-973. doi: 10.2215/CJN.08781010.

39. Ho KM, Power BM. Benefits and risks of furosemide in acute kidney injury. Anaesthesia. 2010;65(3):283-293. doi: 10.1111/j.1365-2044.2009.06228.x.

40. Cantarovich F, Rangoonwala B, Lorenz H, Verho M, Esnault VL, High-Dose Flurosemide in Acute Renal Failure Study Group. High-dose furosemide for established ARF: a prospective, randomized, double-blind, placebo-controlled, multicenter trial. Am J Kidney Dis. 2004;44(3):402-409. doi: 10.1053/j. ajkd.2004.05.021.

41. van der Voort PH, Boerma EC, Koopmans M, et al. Furosemide does not improve renal recovery after hemofiltration for acute renal failure in critically ill patients: a double blind randomized controlled trial. Crit Care Med. 2009;37(2):533-538. doi: 10.1097/CCM.0b013e318195424d.

42. Costa e Silva VT, Liano F, Muriel A, Diez R, de Castro I, Yu L. Nephrology referral and outcomes in critically ill acute kidney injury patients. PLoS One. 2013;8(8):e70482. doi: 10.1371/journal.pone.0070482

43. Karvellas CJ, Farhat MR, Sajjad I, et al. A comparison of early versus late initiation of renal replacement therapy in critically ill patients with acute kidney injury: a systematic review and meta-analysis. Crit Care. 2011;15(1):R72. doi: 10.1186/cc10061.

44. Zarbock A, Kellum JA, Schmidt C, et al. Effect of early vs delayed initiation of renal replacement therapy on mortality in critically ill patients with acute kidney injury: the ELAIN randomized clinical trial. JAMA. 2016;315(20):21902199. doi: 10.1001/jama.2016.5828.

45. Gaudry S, Hajage D, Schortgen F, et al. Initiation strategies for renal-replacement therapy in the intensive care unit. N Engl J Med. 2016;375(2):122-133. doi: 10.1056/NEJMoa1603017

46. Meersch M, Kullmar M, Schmidt C, et al. Long-term clinical outcomes after early initiation of RRT in critically ill patients with AKI. J Am Soc Nephrol. 2018;29(3):1011-1019. doi: 10.1681/ASN.2017060694.

47. Barbar SD, Binquet C, Monchi M, Bruyere R, Quenot JP. Impact on mortality of the timing of renal replacement therapy in patients with severe acute kidney injury in septic shock: the IDEAL-ICU study (initiation of dialysis early versus delayed in the intensive care unit): study protocol for a randomized controlled trial. Trials. 2014;15:270. doi: 10.1186/1745-6215-15-270.

48. Smith OM, Wald R, Adhikari NK, et al. Standard versus accelerated initiation of renal replacement therapy in acute kidney injury (STARRT-AKI): study protocol for a randomized controlled trial. Trials. 2013;14:320. doi: 10.1186/17456215-14-320.

49. Vinsonneau $C$, Camus $C$, Combes $A$, et al. Continuous venovenous haemodiafiltration versus intermittent haemodialysis for acute renal failure in patients with multiple-organ dysfunction syndrome: a multicentre randomised trial. Lancet. 2006;368(9533):379-385. doi: 10.1016/S0140-6736(06)69111-3. 